\title{
TEACHING SPEAKING THROUGH PICTURE SERIES
}

\author{
Putri Nur Azijah Mailani' ${ }^{1}$, Rida Farhana ${ }^{2}$ \\ ${ }^{1}$ IKIP Siliwangi \\ ${ }^{2}$ IKIP Siliwangi \\ ${ }^{1}$ putri3melani@gmail.com, ${ }^{2}$ sabrinaridafarhana07@gmail.com,
}

\begin{abstract}
The objective in this research was to find out whether or not The use of Picture Series in Teaching Speaking was effective to improve the students' speaking ability to in Junior High School. In this research the writer used one group pretest-posttest designs. The population of this research in FirstGrade class students of the Junior High School and the sample in First class. The instrument of this research was speaking test. The data of this research were collected by giving pretest and posttest. Then, The collected data was calculated by using SPPS version 24 . The result of this research show, that Normality distribution value of pretest 0.132 and significance values of posttest is 0.200 the data was normal because both of significance value more than 0.05 , and significance value (2-tailed) of t-test lower than 0.05. It mean the null hypothesis ( но $_{\text {) }}$ is rejected.Thus, it can be concluded The use of picture series in teaching speaking is effective in improving students speaking ability, it is similar to this research.
\end{abstract}

Keywords: Picture Series, Speaking Skill

\section{INTRODUCTION}

In this modern era English is an international language. We must learn and speak English because of the fact that it has become the language used by mean of people in different countries to interction with each other. English currently has an important role in the world because English is used in various fields such as sciences, pharmacy, and business not only in education. English in Indonesia as a foreign language is not a second language for the reason that only some people in Indonesia can speak English. In the event that we can to speak English, therefore we have the ability to know the development of technology and can to communicate with people who visit from other countries.

In Indonesia English lesson is taught from elementary school in order to college level, also taught to be used in daily activities or any condition or situation. However, Speak English for most people is difficult, because pronunciation also different from the Indonesian language. In addition, the English language makes people fear to pronounce wrongly, feeling less confident, limited vocabulary therefore they do not dare to speak in English. (Lado, 1977) states that talking is depicted as a capacity to speak or to express an arrangement of thoughts fluidly.

According to As (Kayi, 2006), Picture series is a number of Pictures which representation of anything (as a person, produced means of painting, drawing, engraving, photography, etc) in applying a strategy of teaching. (Sardiman, 2001) also stated that picture series is a number of pictures that show events and have correlation from one to another. It means, from the picture series can create a story from beginning to the end.

One of the interesting techniques in teaching English is using picture. The advantages of these technique students must describe the pictures with their vocabulary also easy to set, interesting, meaningful, and can to develop students' English language skills. We can to change their 
thinking from English is hard to learning English is easy and fun. Therefore this research entitled "Teaching Speaking Through Picture Series" is to see whether students speaking skills can be improved by applying the technique.

Based on the previous description, research questions in this study:

a. Is the using series of pictures technique effective to improve the students speaking ability?

Thus, based on the description above, the objectives of this study is whether or not The use of picture series in teaching speaking was effective to improve the students' speaking ability to the Seventh Grade Students of MTS Al- Amanah Bandung.

\section{Speaking Skills}

Tarigan (1981:15) in (Episiasi, Ardayati, \& Novianti, 2015) states that speaking is a skill of conveying words or sounds of articulation to express or to deliver ideas, opinions, or felling.It is supported by (Irawati, 2014) defines speaking as an activity to produce sayings in the form of words and sentences orally in order to communicate with others. While, (Anderson \& Kenneth, 2004) states that study speaking has been influenced by the findings of research into the relationship between classroom communication practice and overall progress in foreign language.

Moreover, (Thornburry, 2005) describe that, it was mistakably assumed that the ability to speak fluently are the results from the teaching of grammar and vocabulary. Yet, be maintains that speaking is much more complex than just grammar and vocabulary. It involves many aspects such as command skill and other knowledge.

Based on the previous definitions of speaking, the researchers concludes that speaking is a process of conveying meaning to other persons in various contexts. To be a good speaker, a person should ace a few parts of talking. A portion of the perspectives are familiarity, exactness and conceivability. In this manner, the scientist makes an operational definition out of talking abilities for this examination as the aptitudes to fabricate and share importance with other individuals smoothly, precisely and understandably.

\section{Picture Series Technique}

According to (Daryanto, 2016) Picture Series is a learning method that use images and is paired / sorted into a logical sequence. In addition As (Kayi, 2006), Picture series is a number of Pictures which representation of anything (as a person, produced means of painting, drawing, engraving, photography, etc) in applying a strategy of teaching.

In teaching speaking skills, there are several principles that should be considered by the teacher. One of the important principles is to provide something for learners that will encourage or stimulate them to talk. There are many things that can be to fortify them to talk. For this situation, visual boosts as a photo arrangement were utilized as a part of instructing talking. Connecting to visual or aural jolts, (Hill, 1990) says that visuals have the favorable circumstances
a. of being modest,
b. of being accessible as a rule,
c. of being close to home, that is, they are chosen by the educator, which prompts a programmed sensitivity amongst instructor and materials,
d. consequent eager utilize, and
e. of bringing images into the unnatural world of the language classroom. 
Moreover, (Harmer, 1991) brings up that the educator can fortify the understudies to create oral pieces by demonstrating to them a progression of pictures, emulating a story, or playing them a tape with a progression of sounds. Therefore, the Pictures Series Technique was used in teaching and learning speaking. In addition, (Bailey, K, 2005) states that, in a speaking lesson, pictures and "manipulables" can provide the motivation for talking. Then, he also stated:

Using pictures as the basis of speaking lessons also gives the learners something to talk about, something to focus on other than their own uncertainty with the new language. Regardless of whether you utilize shaded photos from logbooks, ads pattern from magazines, or pictures you situate on the web, pictures add enthusiasm to talking exercises and can propel individuals to talk.

(Bailey, K, 2005) Speaking and writing are both beneficial aptitudes and pictures can regularly be utilized as a part of comparable approaches to advance them (Wright, 2004) furthermore expresses that photos can fortify and give data to be alluded to in discussion and discourse as in narrating. Moreover, (Bowen \& B, 1991) states that a sequence of pictures are a series of pictures on a single subject. They reveal their story or theme, like a strip cartoon. In a connected set of illustrations, for good selection and display, the teacher must:

b. Make the titles and captions large enough to read, or omit them all together and do the describing orally;

c. Link pictures. There should be continuity of characterization, setting and subject from picture to picture, with figures of uniform size and recurring landmarks;

d. If book or magazine representations are replicated, they ought to be disentangled and parts not basic to encouraging points ought to be forgotten;

e. The pictures themselves should all be the same size and similarly mounted in order to make a set.

\section{METHOD}

In this research the research used quantitative method (Crowl, 1997) state that "quantitative research method is used to examine questions that can be best answered by collecting and statistically analyzing data".

Instrument is any device which is used to collect data (Tavakoli, 2012). Instrument can be presented in written, audio, or visual format. The Research used pretest and posttest as a instrument. Pretest was given to find out how well the students speaking ability without series of pictures, treatment was given series of pictures, and posttest was given instruction each students oral test about materials. Pretest and Posttest contained the same given instruction oral test. Then, The writer use SPSS IBM 24.0 version, to analyze SPSS should be calculated mean, standard deviation, normal distribution, and T-test. 


\section{RESULTS AND DISCUSSION}

\section{Results}

The students' detail score can be seen in the following table :

Table 1 Detail of Pretest and Posttest Score

\begin{tabular}{|c|c|c|c|}
\hline Name & Pretest & Posttest & Gain \\
\hline Student 1 & 44 & 56 & 12 \\
\hline Student 2 & 60 & 68 & 8 \\
\hline Student 3 & 48 & 64 & 16 \\
\hline Student 4 & 52 & 72 & 20 \\
\hline Student 5 & 44 & 60 & 16 \\
\hline Student 6 & 48 & 56 & 8 \\
\hline Student 7 & 60 & 64 & 4 \\
\hline Student 8 & 48 & 72 & 24 \\
\hline Student 9 & 68 & 76 & 8 \\
\hline Student 10 & 56 & 60 & 4 \\
\hline Student 11 & 40 & 56 & 16 \\
\hline Student 12 & 44 & 52 & 8 \\
\hline Student 13 & 40 & 72 & 32 \\
\hline Student 14 & 56 & 76 & 20 \\
\hline Student 15 & 52 & 60 & 8 \\
\hline Student 16 & 60 & 68 & 8 \\
\hline Student 17 & 44 & 76 & 32 \\
\hline Student 18 & 40 & 72 & 32 \\
\hline Student 19 & 60 & 68 & 8 \\
\hline Student 20 & 56 & 64 & 8 \\
\hline Student 21 & 64 & 88 & 24 \\
\hline Student 22 & 68 & 72 & 4 \\
\hline Student 23 & 72 & 76 & 4 \\
\hline Student 24 & 64 & 88 & 24 \\
\hline Student 25 & 40 & 64 & 24 \\
\hline Student 26 & 52 & 76 & 24 \\
\hline Student 27 & 64 & 72 & 8 \\
\hline Student 28 & 76 & 80 & 4 \\
\hline Student 29 & 40 & 68 & 28 \\
\hline Student 30 & 44 & 76 & 32 \\
\hline Student 31 & 80 & 88 & 8 \\
\hline
\end{tabular}

\section{Data Statistics}

For find normality data the researcher used SPSS IBM 24.0 version. The first steps that be find Test of Normality. The researcher chose the data of Kolomgrov -Smirnov, because the sample more than 30 students.

Table 2 Detail Test of Normality Tests of Normality

\begin{tabular}{lc|c|c|c|c|c}
\hline & \multicolumn{3}{c}{ Kolmogorov-Smirnov $^{\mathrm{a}}$} & \multicolumn{3}{c}{ Shapiro-Wilk } \\
& Statistic & Df & Sig. & Statistic & Df & Sig. \\
\hline Pretest & .139 & 31 & .132 & .935 & 31 & .060 \\
Posttest & .123 & 31 & $.200^{*}$ & .957 & 31 & .235 \\
\hline
\end{tabular}


Based on the table 2 Normality test can be said normal if significant value more than 0.05 , the data was taken based on data Kolmogorov-smirnov because the data more than 30 students and significance value of pretest is 0.132 and significance value of posttest is 0.200 . It means that both of significance value was normal then the writer doing the next step is to find out the value of homogeneity of variances in order to know the data was homogeneity or not homogeneity.

Table 3 Detail Test of Homogeneity of Variances

Test of Homogeneity of Variances

\begin{tabular}{|c|c|c|c|}
\hline pretest & & & \\
\hline $\begin{array}{l}\text { Levene } \\
\text { Statistic }\end{array}$ & df1 & $\mathrm{df} 2$ & Sig. \\
\hline .976 & 6 & 22 & .465 \\
\hline
\end{tabular}

Based on the table 3 homogeneity of variances can be said normal if significance value more than 0.05 based on data above its significance value of homogeneity of variances is 0.465 . The significance value was homogeneity then the writer doing the next step is to find out the value of one sample t-test

Table 4 Detail One-Sample Test One-Sample Test

\begin{tabular}{cc|c|c|c|c|c} 
& & & \multicolumn{2}{c}{ Test Value $=0$} \\
& & & $\begin{array}{c}\text { Sig. (2- } \\
\text { tailed) }\end{array}$ & $\begin{array}{c}\text { Mean } \\
\text { Difference }\end{array}$ & $\begin{array}{c}\text { 95\% Confidence Interval of } \\
\text { the Difference } \\
\text { Lower }\end{array}$ & Upper \\
\hline Pretest & 26.430 & 30 & .000 & 54.323 & 50.12 & 58.52 \\
\hline Posttest & 41.040 & 30 & .000 & 69.677 & 66.21 & 73.14 \\
\hline
\end{tabular}

Based on the table $4 \mathrm{t}$-observed from pretest was 26.430 and the t observed from posttest was 41.040. The degree of freedom of this test was 30 for both of pretest and posttest, significance value (2-tailed) lower that 0.05 the significance value (2-tailed) is 0.000 . It means that the null hypothesis (Ho) is rejected.

\section{Discussion}

From the result about it can be stated that using series of pictures has a significantly better and can improve on students speaking ability.There are three tables that was calculated they are Normality distribution value of pretest 0.132 and significant values of posttest is 0.200 the data was normal because both of significant value more than 0.05 , significant value of homogeneity of variances is 0.465 the data was normal because significant value of homogeneity of variances more than 0.05 , significant value (2-tailed) of t-test lower than 0.05 based on data above its significant value (2-tailed) is 0.000 . It mean the null hypothesis (но) is rejected and The using of series of pictures is effective in improving students speaking ability, it is similar to this research. 


\section{CONCLUSION}

The Conclusion should contain the confirmation of the problem that has been analyzed in result and discussion section. The Conclusion should contain the confirmation of the problem that has been analyzed in result and discussion section. The Conclusion should contain the confirmation of the problem that has been analyzed in result and discussion section.

\section{ACKNOWLEDGMENTS}

The researchers greatest apperciation to IKIP Siliwangi.The Head of English Education Study Program. The researchers also want to deliver our sincere thank to our advisor, who already gave us suggestions and guidance which are useful to finish our journal. The researcher also thank to all lecturers in English Education Study Program for the time and share your knowledge.

\section{REFERENCES}

Anderson, \& Kenneth. (2004). Study Speaking. New York: Cambridge University Press.

Bailey, K, M. (2005). Practical English Language Teaching. New York: McGraw Hill.

Bowen, \& B, M. (1991). Look Here! Visual Aids in Language Teaching. London: Modern English Publishers.

Crowl, T. K. (1997). Fundamentals of Education Research (Second Edition). USA: Times Mirror Higher Education Group, Inc.

Daryanto. (2016). Media Pembelajaran. Gaya Media.

Episiasi, Ardayati, \& Novianti. (2015). the effectiveness of using pictures to improve students' speaking skill. Smart Journal, 1, 93-101.

Harmer, J. (1991). The Practice of English Language Teaching. London: Longman Group.

Hill, D. A. (1990). Visual Impact: Creative Language Learning through Pictures. Harlow: Longman.

Irawati, I. (2014). Improving students' speaking ability through communicative language games. Magistra, 87, 25-36.

Kayi, H. (2006). Teaching Speaking Activity to Promote Speaking. Nevada: University of Nevada.

Lado, R. (1977). Language Testing. New York: Mc. Graw Hill.

Sardiman, A. . (2001). Interaksi dan Motivasi Belajar mengajar. Jakarta: PT Bina Aksara.

Tavakoli, H. (2012). A Dictionary of Research Methodology and Statistics in Applied Linguistics. tehran: Rahnama Press.

Thornburry, S. (2005). How to Teach Speaking. Longmann: Pearson Education Limited.

Wright, A. (2004). Pictures for language Learning. Cambridge, UK: Cambridge University Press. 